\section{Community behavior in control of rats in Leptospirosis transmission areas in Pacitan Regency, Indonesia}

\author{
Ririh Yudhastuti, M. Farid D. Lusno, \\ Aditya Sukma Pawitra \\ Department of Environmental Health, \\ Faculty of Public Health, Universitas \\ Airlangga, Indonesia
}

\begin{abstract}
Based on basic health research data at the end of March 2017, 23 patients were reported with positive Leptopsirosis with at least 8 deaths in Pacitan district, East Java. Leptospirosis is spread in 5 sub-districts in Pacitan Regency, namely Ngadirojo, Tulakan, Kebon Agung, Arjosari and Punung. The purpose of the study was to determine the factors that influence the control behavior of mice in the area at risk of transmission of leptospirosis. Explanatory study with survey research methods was used in this study. 92 families affected by leptospirosis were recruited through simple random sampling. The results showed that the role of health workers who are active in eradicating rats has 5.3 times the possibility of good behavior in eradicating rats when compared with the role of health workers who are less active. It can be concluded that knowledge, attitudes, information availability, and the role of health workers influence the control behavior of mice in areas at risk of leptospirosis transmission in the community.
\end{abstract}

\section{Introduction}

Leptospirosis is an acute disease-borne disease (zoonosis). This disease is caused by Leptospira bacteria with a broad spectrum of diseases and can cause death. Leptospirosis is an infection caused by a spiral-shaped bacterium called Leptospira interrogans. In Indonesia, leptospirosis is spread among others in West Java Province, Central Java Province, Yogyakarta Special Region, Lampung Province, Bengkulu, Riau, West Sumatra, North Sumatra, Bali, West Nusa Tenggara, North Sulawesi. East Kalimantan and West Kalimantan. The death rate from leptospirosis is high, reaching 2.5-16.45 percent. At the age of more than 50 years the death reaches 56 percent. Leptospirosis patients accompanied by eye membranes yellow (liver tissue damage) have a higher risk of death, hospital mortal- ity due to leptospirosis $3-54 \%$ and depend on the system of infected organs. ${ }^{1,2}$

Data from the International Leptospirosis Society (ILS), Indonesia is a country ranked 3 (three) incidents of leptospirosis in the world after India and China for mortality. Climate conditions that are suitable for the development of Leptospira are warm air, wet soil and alkaline $\mathrm{pH}$, this condition is found in tropical countries. Therefore, cases of Leptospirosis 1000 times more commonly found in tropical countries compared to subtropical countries with the risk of disease more severe. The incidence of Leptospirosis in wet tropical countries is $5-20 / 100,000$ populations per year. The World Health Organization (World Health Organization/WHO) notes, cases of Leptospirosis in subtropical climates are estimated at $0.1-1$ per 100,000 people each year, whereas in tropical climates this case increases to more than 10 per 100,000 people each year. ${ }^{1,3}$ More than 100 people from high-risk groups among 100,000 people can be infected. Based on data from the Pacitan District Health Office report on Prevention of Disease Eradication (P2P) in 2017 leptospirosis cases occurred in several villages in 5 sub-districts in Pacitan Regency, namely Ngadirojo, Tulakan, Kebon Agung, Arjosari and Punung. ${ }^{4}$ The formulation of the problem in this study is "What Factors Affect the Behavior of Mouse Control in Communities in Leptospirosis Endemic Areas?"

\section{Materials and Methods}

This study is an explanatory study which explains the relationship between independent variables and the dependent variable, aimed at knowing the factors that influence rat control behavior in people in endemic areas of leptospirosis. The independent variables in this study were knowledge, attitudes, availability of information and the role of health workers while the dependent variable was rat control behavior. 92 families affected by leptospirosis were recruited through simple random sampling. ${ }^{5}$

Univariate analysis is presented in the form of a frequency distribution table, while bivariate analysis consists of table analysis or crosstab, influence analysis. Cross tabulation analysis is used to summarize and find out the distribution of data and can also be used to analyze descriptively. Correlation analysis is the basis for testing the research hypothesis using the ChiSquare test. For multivariate analysis of logistic regression analysis to predict the dominant variable in the pattern of influence between variables in this case, knowl-
Correspondence: Ririh Yudhastuti, Department of Environmental Health, Faculty of Public Health, Universitas Airlangga, Jl. Mulyorejo, Surabaya, Jawa Timur 60115, Indonesia.

Tel: +62315920948 - Fax: +62315924618

Email: ririh.unair@gmail.com.

Key words: community behavior, leptospirosis endemis areas, rat eradication.

Contributions: the authors contributed equally.

Conflict of interests: the authors declare no potential conflict of interests.

Funding: none.

Conference presentation: part of this paper was presented at the 3rd International Symposium of Public Health, 2018 October 31- November 1, Universitas Airlangga, Surabaya, Indonesia.

Dedication: the article is dedicated to Faculty of Public Health, Universitas Airlangga, Surabaya, Indonesia.

Received for publication: 28 July 2019. Revision received: 9 September 2019.

Accepted for publication: 15 October 2019.

This work is licensed under a Creative Commons Attribution NonCommercial 4.0 License (CC BY-NC 4.0).

${ }^{C}$ Copyright: the Author(s), 2019

Licensee PAGEPress, Italy

Journal of Public Health in Africa 2019; 10(s1):1213 doi:10.4081/jphia.2019.1213

edge, attitude, availability of information and the role of health workers associated with leptospirosis control behavior.

\section{Results}

The characteristics of the respondents, for the age group of the respondents who were the most were between $37-60$ years old as much as $78.3 \%$, the age variable of the respondents was the lowest 29 years and the highest was 75 years. Respondents who had elementary school education were $33.7 \%$ and with a higher education $34 \%$. The sex of the most respondents is $62.2 \%$. Average respondents' income $(\geq \mathrm{Rp}$. $1,750,000$ ) was about $51 \%$

Knowledge from respondents regarding control of leptospirosis through eradication of mice was (less) $34.8 \%$, inadequate $(31.5 \%)$, good $(33.7 \%)$ eradication of the most mice namely lack of knowledge as 
much as $34.8 \%$, good $33.7 \%$ and enough $31.5 \%$. The attitude of respondents to the control of leptospirosis through eradication of the most rats is to support as much as $53.3 \%$ and not support $46.7 \%$. While the availability of information in controlling leptospirosis with eradication of mice, the majority of respondents provided information as much as $48.5 \%$ and no information available $51.5 \%$. For behavior in eradicating mice as much as $52.2 \%$ and $47.8 \%$ was not very good.

Percentage of rat eradication behavior that was not good in respondents 'lack of knowledge $(81.2 \%)$ was greater than respondents' knowledge $(37.9 \%)$ and good knowledge $(22.6 \%)$. The percentage of good rat eradication behaviors in the respondents 'good knowledge (77.4\%) was greater than the respondents' sufficient knowledge $(62.1 \%)$ and lack of knowledge $(18.8 \%)$. The test results of the analysis of the Chi-Square test showed that $\mathrm{p}=0.0001$ which means $\mathrm{p}<0.05$, Ha is accepted or there is a significant relationship between the knowledge of respondents and eradication behavior in areas at risk of transmission of leptospirosis. Percentage of rat eradication behavior that was not good in respon- dents with a non-supportive attitude $(69.8 \%)$ was greater in respondents' supportive attitude $(28.6 \%)$. The percentage of good rat eradication behavior in the respondents 'supportive attitude (71.4\%) was greater than the respondents' attitude of not supporting (30.2\%). The test results of the relationship analysis with Chi-square test showed that $\mathrm{p}=0.0001$ which means that $\mathrm{p}$ $<0.05$ then $\mathrm{Ha}$ is accepted or there is a significant relationship between the attitude of respondents with eradication behavior in endemic areas of leptospirosis or coarse areas of leptospirosis transmission in Pacitan

Table 1 shows the relationship between availability information with rat eradication behavior. $79.3 \%$ respondents have less rat eradication behavior due to unavailability of information. The percentage of good rat eradication behavior in the respondents who had information $(66.7 \%)$ was greater than the respondents' who did not have much information $(20.7 \%)$. The results of the ChiSquare test showed that $\mathrm{p}=0.0001$ which means that $\mathrm{p}<0.05, \mathrm{Ha}$ is accepted or there is a significant relationship between the availability of information and eradication behavior of leptospirosis in endemic areas.
The role of inactive health workers $(68.9 \%)$ is greater than the role of active health workers $(27.7 \%)$. The percentage of good rat eradication behavior on the role of active health workers $(72.3 \%)$ is greater than the role of inactive health workers (31.1\%) (Table 2). The results of the analysis of the relationship with the Chi-Square test showed that $\mathrm{p}=0.0001$ which means that $\mathrm{p}<0.05$, Ha is accepted or there is a significant relationship between the role of health workers and eradication behavior of leptospirosis endemic areas.

From the 4 independent variables, namely knowledge, attitudes, information availability and the role of health workers after the relationship test, it was proven to have a significant relationship with the dependent variable, namely the knowledge variable with eradicating behavior in leptospirosis endemic areas. with a value of $p$ $<0.05$, that is at $p=0.0001$, attitude variable with rat eradication behavior with a value of $\mathrm{p}<0.05$, that is at $\mathrm{p}=0.0001$, variable availability of information with the delivery behavior of mice with a value of $p<0.05$ which is at $p=0.0001$ and the variable role of health workers with a value of $p<0.05$ which is at $\mathrm{p}=0.0001$.

Table 1. Relationship between availability information with rat eradication behavior.

\begin{tabular}{|c|c|c|c|c|c|c|}
\hline \multirow[t]{2}{*}{ Availability Information } & \multicolumn{4}{|c|}{ Rat Behavior Eradication } & \multicolumn{2}{|c|}{ Total } \\
\hline & N & $\%$ & $\mathbf{N}$ & $\%$ & $\mathbf{N}$ & $\%$ \\
\hline Information available & 21 & 33.3 & 42 & 66.7 & 63 & 100.0 \\
\hline Information not available & 23 & 79.3 & 6 & 20.7 & 29 & 100.0 \\
\hline Total & 44 & & 48 & & 92 & \\
\hline
\end{tabular}

$\mathrm{X}^{2}=16.823 ; \mathrm{p}=0.0001 ;$ Ho $=$ rejected.

Table 2. Relationship between role of health officers and rat eradication behavior.

\begin{tabular}{|c|c|c|c|c|c|c|}
\hline \multirow[t]{3}{*}{ Availability Information } & \multicolumn{5}{|c|}{ Rat Behavior Eradication } & \\
\hline & & & & & & \\
\hline & $\mathbf{N}$ & $\%$ & $\mathbf{N}$ & $\%$ & $\mathbf{N}$ & $\%$ \\
\hline Active & 13 & 27.7 & 34 & 72.3 & 47 & 100 \\
\hline Not active & 31 & 69.9 & 14 & 31.1 & 45 & 100 \\
\hline Total & 44 & & 48 & & 92 & \\
\hline
\end{tabular}

$\mathrm{X}^{2}=16.823 ; \mathrm{p}=0.0001 ; \mathrm{Ho}=$ rejected.

Table 3. Multivariate test.

\begin{tabular}{llcccccccc} 
No & Variable & B & SE & Wald & Df & Sig & Exp(B) & $\begin{array}{c}95 \% \text { CI for EXP } \\
\text { Upper } \\
\text { Lower }\end{array}$ \\
\hline 1 & Knowledge & 1,035 & 0,374 & 7,678 & 1 & 0,006 & 2,815 & 1,354 & 5,855 \\
2 & Attitude & 1,556 & 0,594 & 6,856 & 1 & 0,009 & 4,740 & 1,479 & 15,192 \\
\hline 3 & Information & 1,651 & 0,64 & 6,655 & 1 & 0,010 & 5,215 & 1,487 & 18,286 \\
4 & The role of officers & 1,672 & 0,59 & 8,042 & 1 & 0,005 & 5,323 & 1,676 & 16,903 \\
\hline
\end{tabular}


Logistic Regression is a multivariate analysis that aims to find out which independent variables influence rat eradication behavior. This analysis uses logistic regression test with enter method, with a confidence level of $95 \%$, after multivariate analysis the results are shown in Table 3 . Knowledge variable, in eradicating rats showed significance where the value of $\mathrm{p}=$ $0.006(\mathrm{p}<0.05)$ with $\mathrm{OR} / \operatorname{Exp}(\mathrm{B})=2.815$ (95\% CI: 1,354-5,855). This means that respondents' good knowledge about eradicating rats has 2 times the possibility of good behavior in eradicating rats, when compared with respondents who have less knowledge. The attitude variable, against the eradication of rats showed significance where the value of $p=0.009(p<0.05)$ with $\mathrm{OR} / \operatorname{Exp}(\mathrm{B})=4.740 \quad(95 \%$ CI: $1.474-$ 15,192). This means that the attitude of respondents who support the eradication of rats has 4 times the possibility of good behavior in eradicating mice in leptospirosis endemic areas, when compared with respondents who have an attitude that is not supportive.

Variable information availability, in eradicating rats showed where the value of $\mathrm{p}=0.010(\mathrm{p}<0.05)$ with $\mathrm{OR} / \operatorname{Exp}(\mathrm{B})=$ 5.215 (95\% CI: $1.487-18,286)$. This means that the availability of information in eradicating rats has 5 times the possibility of good behavior in eradicating rats when compared with respondents who have no information available. Variable role of health workers, in eradicating rats showed a value of $\mathrm{p}=0.005(\mathrm{p}<0.05)$ with OR / Exp $(B)=5.323$ (95\% CI: 1.676-16.903). This means that public perceptions of the role of health workers who are active in eradicating mice in leptospirosis endemic areas have 5 times the possibility that people will behave well in eradicating mice when compared to the role of less active health workers.

From the regression coefficient value, the variable role of health workers $(0.005)$ is more dominant/strong influence when compared to the knowledge variable (0.006), attitude (0.009), and information availability (0.01).

\section{Discussion}

The results showed that respondent who had less knowledge had good rat eradication behaviors of $18.8 \%$, and that eradicating behavior was $81.2 \%$. Knowledge in this study is the understanding of respondents about the notion of mice as transmitters of leptospirosis, clinical manifestations of leptospirosis, transmission of leptospirosis, place and time of activity of the presence of mice and eradication of mice. When it is associated with a supportive attitude, the availability of information about eradicating mice and the role of health workers in providing counseling to eradicate mice that are at risk of transmitting leptospirosis and the activity of respondents to seek information and counseling from health cadres will influence rat eradication behavior.

Knowledge is the result of knowing and happening after people have sensed something specific object. Most human knowledge is obtained from the eyes and ears. Knowledge covered has six levels, namely 1) know; 2) understand; 3) application; 4) analysis; 5) synthesis and 6) evaluation. The results of statistical analysis showed a significant relationship $(\mathrm{p}=0,0001)$ level of knowledge of respondents with eradication behavior. $^{6}$ Knowledge is a very important domain for the formation of one's actions because from experience it turns out that behavior based on knowledge will be more lasting than behavior that is not based on knowledge. ${ }^{7}$ A person's belief in health is partly formed by intellectual variables which consist of knowledge of various bodily functions and diseases, educational background and past experience. Cognitive abilities influence ways of thinking, including the ability to understand factors related to health and use the knowledge they have to maintain their own health. 7,8

Individual and community knowledge is a predisposing factor that can facilitate behavior change. The presence of external stimuli can cause behavior in the form of knowledge to change to better knowledge, including rat eradication behavior. A significant relationship between knowledge and rat eradication behavior means that the increase in knowledge about eradicating rats will increase or have a greater chance of eradicating rodents. ${ }^{9}$ Regression logistic test results obtained good respondents' knowledge about eradication of rats having 2.8 times the possibility of good behavior in eradicating rats, when compared with respondents who have less knowledge. The results showed that respondents who had a position to support good rat eradication behavior were $71.4 \%$ and those with poor eradication behavior were $28.6 \%$. The majority of respondents have supportive attitudes such as eradicating rats and burning rat carcasses to prevent transmission of leptospirosis using mouse traps, installing wire netting and closing food containers. But the attitude about the use of footwear, most respondents did not support. This is likely to assume that the use of footwear is only used in the yard at the time when the soil conditions are muddy, when the floods leave the footwear. 9 The high attitude towards eradicating mice is caused by the motivation of health workers, the availability of information on eradicating mice and every year leptospirosis always there even though the research results of respondents' knowledge are not good. One of the factors that influence changes in a person's attitude is the cognitive component that contains a person's beliefs about the object of attitude. Trust comes from what we see or what we have known which then forms an idea or idea. ${ }^{10}$ Attitude is a predisposing factor that simplifies behavior change, and attitude is self-response from the results of stimulation of others who express support or not support where it is better that it agrees it is easier to change rat eradication behavior. ${ }^{11}$ Respondents who have positive attitudes tend to have better behavior in eradication of rats.

The results of the statistical analysis showed that there was a significant relationship between attitudes and rat eradication behavior $(p=0.001 / p<0.05)$. This is in accordance with previous research, which states that attitude factors have a significant relationship to rat eradication behavior. ${ }^{6}$ Regression logistic test results obtained attitudes of respondents who support the eradication of rats have 4.7 times the possibility of good behavior in eradicating rats, compared with the other respondents. The results showed that the percentage of good rat eradication behavior in the respondents who had information $(66.7 \%)$ was greater than the respondents' who did not have much information (20.7\%) respondents. Public health information provides health messages for community and it comes from a variety of sources, such as health care professionals, social media, family and social networks. Availability of information is an enabling factor for the occurrence of a behavior. The results of the statistical analysis showed a significant relationship ( $p$ $<0.05$ ) availability of information with rat eradication behavior. A significant relationship between the availability of information and rat eradication behavior means that the increased availability of information about eradicating rats will also have a greater chance of eradicating rodents in areas at risk of transmission of leptospirosis. ${ }^{12}$ Regression logistic test results obtained where the availability of information available in eradicating rats, then 5.2 times the probability of respondents going to eradicate rat behavior in the area at risk of transmission of leptospirosis. he results of the study showed that respondents whose role was active health workers in eradicating the behavior of rats was $72.3 \%$ and the behavior of eradicating rodents was not as good as $27.7 \%$. The presence of external stimuli (the role of health workers) will affect changes 
in a person's behavior. Counseling provided by health workers in eradicating rats in Pacitan district will affect changes in community behavior in eradicating mice. The counseling was carried out just before the rainy season where many puddles would become leptospirosis transmission sites from the urine of mice. ${ }^{2}$

The role of health workers is a reinforcing factor or weakens the occurrence of behavior change. Counseling provided by health professionals to the community will influence good knowledge and supportive attitudes which will eventually result in good rat eradication behavior. The results of the statistical analysis showed a significant relationship $(\mathrm{p}=0.0001 / \mathrm{p}<0.05)$ between the role of health workers with rat eradication behavior. Counseling will affect one's knowledge better and will form a positive attitude. With the cases of deadly leptospirosis, it makes you aware of rats. In order to avoid leptospirosis, someone will make a movement to eradicate mice in their area.

The regression logistic test results found that the role of health workers who are active in eradicating rats has 5.3 times the possibility of good behavior in eradicating rats when compared with the role of health workers who are less active.

\section{Conclusions}

It can be concluded that there are still many respondents who have poor rat eradication behavior as much as $47.8 \%$. The variables that influence tick eradication behavior are attitudinal knowledge, information and the role of health workers. Among the four variables, the variable role of health workers is the most dominant factor in influencing eradication behavior in areas at risk of leptospirosis transmission.

\section{References}

1. Diament D. Leptospirosis. International Journal of Infectious Diseases 2016;45:40-41.

2. Haake DA, Levett PN. Leptospirosis in Humans. Curr Top Microbiol Immunol 2015;387:65-97.

3. Desakorn V, Wuthiekanun V, Thanachartwet V, et al. Accuracy of a commercial IgM ELISA for the diagnosis of human leptospirosis in Thailand. Am J Trop Med Hyg 2012;86:524-527.

4. Pacitan District Health Officer. Report on Leptospirosis cases; 2017.

5. Kuntoro. Sampling method and determination of sample size. Surabaya:
Pustaka Melati; 2008.

6. Hadi S. Statistics. Yogyakarta: Pustaka Pelajar; 2015.

7. Notoatmojo S. Health Promotion Theory and Application. Jakarta: Rineka Cipta; 2010.

8. Data center and agricultural information system. Climate statistics, plant pest organisms and the impact of climate change 2012-2015. Agricultural Data and information System Center, Secretariat General Ministry of Agriculture; 2015.

9. Sudarmaji S, Singleton GR, Brown P, Jacob J, Herawati NA. Rodent impacts in lowland irrigated intensive rice systems in West Java, Indonesia. In, Singleton et al. (eds.). Rodent outbreaks: ecology and impacts. International Rice Research Institute. Los Banos Philippines. p.115-137; 2010.

10. Notoatmojo S. Health promotion and health behavior. Jakarta: Rineka Cipta; 2014.

11. Ristiyanto R. Rat Disease, Yogyakarta: Gadjah Mada University Press; 2014.

12. Suyanto A. Rodent in Java. Bogor: LIPI; 2006. 